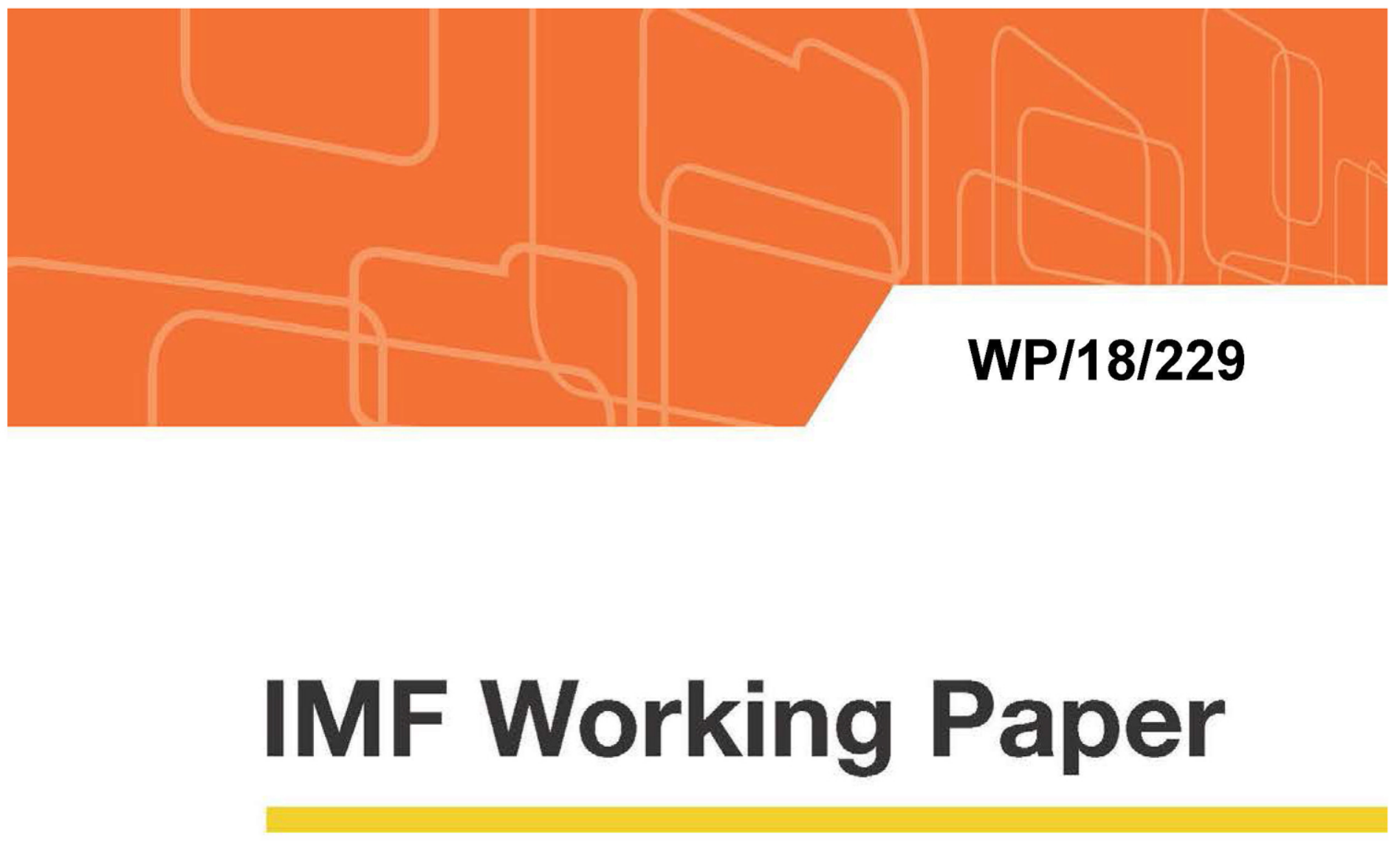

\title{
Measuring Competitiveness in a World of Global \\ Value Chains
}

by Tamim Bayoumi, Maximiliano Appendino, Jelle Barkema, and Diego A. Cerdeiro

IMF Working Papers describe research in progress by the author(s) and are published to elicit comments and to encourage debate. The views expressed in IMF Working Papers are those of the author(s) and do not necessarily represent the views of the IMF, its Executive Board, or IMF management. 


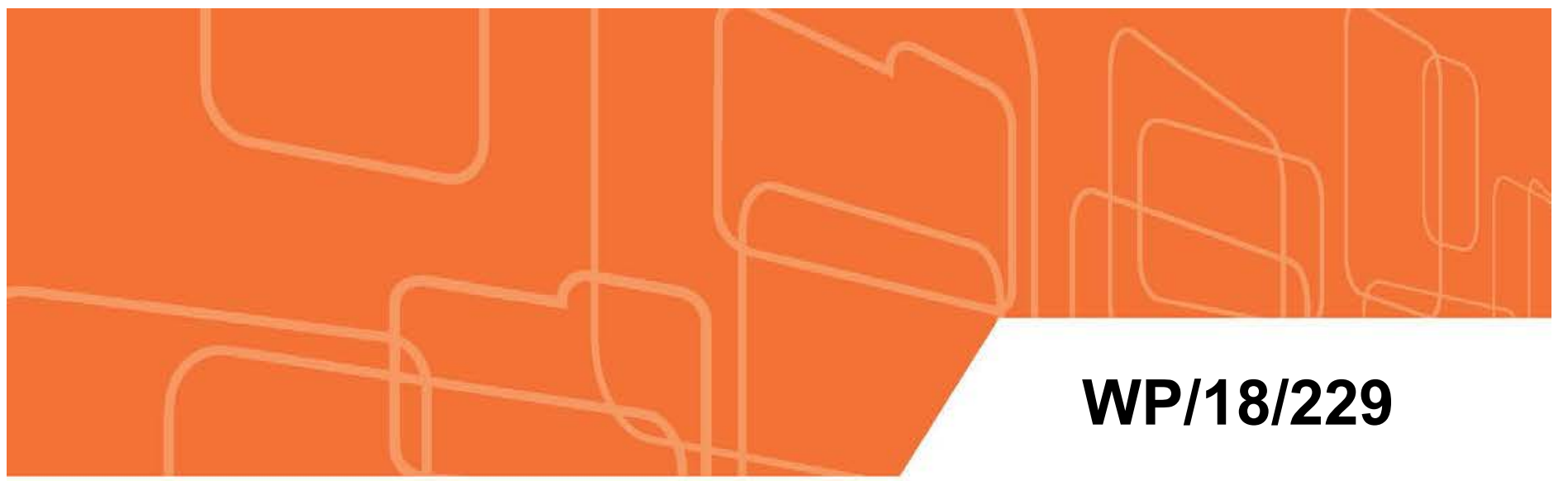

\section{IMF Working Paper}

\section{Measuring Competitiveness in a World of Global Value Chains}

by Tamim Bayoumi, Maximiliano Appendino, Jelle Barkema, and Diego A. Cerdeiro

IMF Working Papers describe research in progress by the author(s) and are published to elicit comments and to encourage debate. The views expressed in IMF Working Papers are those of the author(s) and do not necessarily represent the views of the IMF, its Executive Board, or IMF management. 


\title{
IMF Working Paper
}

Strategy, Policy, and Review Department

\section{Measuring Competitiveness in a World of Global Value Chains}

\section{Prepared by Tamim Bayoumi, Maximiliano Appendino, Jelle Barkema, and Diego A. Cerdeiro ${ }^{1}$}

Authorized for distribution by Martin Mühleisen

November 2018

IMF Working Papers describe research in progress by the author(s) and are published to elicit comments and to encourage debate. The views expressed in IMF Working Papers are those of the author(s) and do not necessarily represent the views of the IMF, its Executive Board, or IMF management.

\begin{abstract}
The fragmentation of production across borders coming from global value chains has resulted in a dramatic increase in trade integration over the last two decades. Conventional competitiveness measures, however, assume that only final products cross borders. This paper argues that, as a result, conventional effective exchange rate calculations underestimate the global nature of competitiveness: too much weight is placed on neighboring countries that belong to the same regional supply chain and too little weight on more distant countries that absorb final goods. We also argue that the nature of the exchange rate regimes across the major currencies, in particular the fact that the dollar has tended to move in close tandem with the renminbi but opposite to the euro, has made it difficult to identify these effects on competitiveness measures in the data. As all major currencies move to greater flexibility, assessments of their relative roles in competitiveness calculations will become more important.
\end{abstract}

JEL Classification Numbers: F15, F17, F62

Keywords: Global value chains, International competitiveness, Trade openness

Author's E-Mail Address: TBayoumi@imf.org; MAppendino@imf.org; JBarkema@imf.org; DCerdeiro@imf.org

\footnotetext{
${ }^{1}$ The authors would like to thank JaeBin Ahn, Malik Bani Hani, Rudolfs Bems, Jack Chen, Sean Craig, Luis Cubbedu, Alfredo Cuevas, James Daniel, Sergei Dodzin, Niels-Jakob Hansen, Artak Harutyunyan, Martin Kaufman, Julie Kozack, Kwangwon Lee, Nan Li, Marco Marini, Jonathan Ostry, Gabriel Quiros, Pau Rabanal, Faezeh Raei, Christoph Rosenberg and Camilo Tovar for helpful comments and suggestions. We are especially grateful to Rudolfs Bems for sharing the effective exchange rate weights developed in Bems and Johnson (2015)
} 
TABLE OF CONTENTS

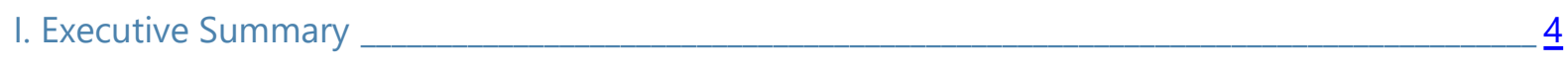

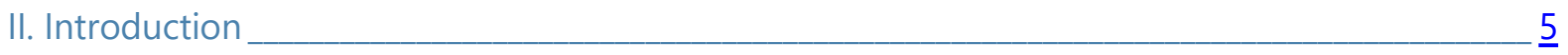

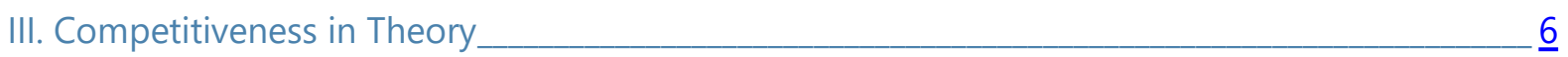

IV. Competitiveness in Practice _________ $\underline{8}$

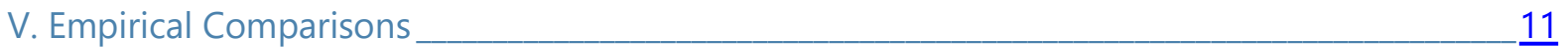

VI. Production and Final Demand Elasticities___________

VII. Dynamic Effective Exchange Rate Weights________

VIII. Trade Openness and Global Value Chains_______

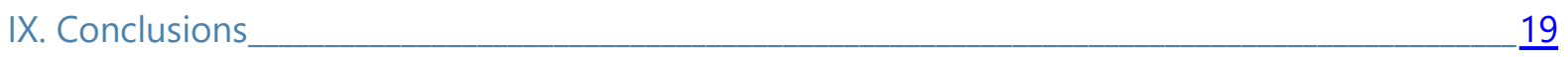

Annex 1. The Theory of Real Effective Exchange Rates________ 21

Annex 2. Estimated Exchange Rate Elasticities Using Different Real Effective Exchange Rates Model__________ $\underline{24}$

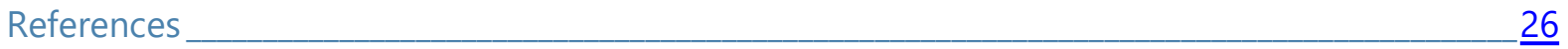

\section{FIGURES}

1. World Intermediate to Gross Exports Ratio

2. Effective U.S., China and Germany Weights for Korea

3. Change in effective exchange rate weights $\underline{13}$

4. Sum of US and China Weights over different REER Measures 2011 $\underline{16}$

5. Average U.S. demand elasticities for intermediate and final demand goods

6. Openness measures in countries that are heavily involved in supply chains is lower when using value-added trade $-\frac{18}{25}$

A1. Import Elasticities with Different REER Measures____________ $\underline{25}$

A2. Export Elasticities with Different REER Measures

$\underline{25}$

\section{TABLES}

1. Correlations of Different Real Effective Exchange Rate Indexes, 1980-2011 $\underline{14}$ 


\section{EXECUTIVE SUMMARY}

Few external indicators are more important for international policy analysis than international competitiveness. Policy makers always want to know how their exports stack up against those of their competitors. Real effective exchange rates, which provide an aggregate measure of changes in international prices by weighting exchange rates based on trade patterns, are the standard metric for measuring such competitiveness. However, these indexes have not incorporated the rise of global value chains in international trade.

The fragmentation of production across borders coming from global value chains has resulted in a dramatic increase in trade integration over the last two decades as the importance of trade in components has risen. Conventional competitiveness measures, however, assume that only final products cross borders. Using Adam Smith's proverbial example, 'pin factories' are assumed to be located entirely within borders. This paper argues that, as a result, conventional effective exchange rate calculations underestimate the global nature of trade competitiveness: too much weight is placed on neighboring countries that belong to the same regional supply chain and too little weight on more distant countries that absorb final goods.

Because supply-chain trade takes place relatively more intensively among regional peers, appropriately accounting for it makes the world smaller from a competitiveness point of view. Exactly how much smaller, it turns out, depends on the flexibility of these supply chains. If supply chains are less flexible, in the sense that the choice of which components to use is little affected by price changes, then competitiveness becomes more global. This is because exchange rate devaluations in countries that supply components, and are often close neighbors, can actually boost a country's exports. This is in stark contrast to the standard result that exchange rate devaluations in other countries lower competitiveness and reduce exports.

Given the significance of the potential changes to how competitiveness should be measured, we also ask, how could the importance of global value chains for competitiveness not have been recognized before? We argue that the nature of the exchange rate regimes across the major currencies, in particular the fact that the dollar has tended to move in close tandem with the renminbi but opposite to the euro, has made it difficult to identify the effects on competitiveness measures in the data. As all major currencies move to greater flexibility, assessments of their relative roles in competitiveness calculations will become more important.

This implies a wide agenda for future work on real effective exchange rates. First, determining the degree of flexibility of global supply chains; this also involves examining how to split components that are highly differentiated and difficult to switch, such as screens for a specific smart phone, from those that are basically identical and easy to switch, such as oil or basic silicon chips; and, finally, providing regular updates of weights to adequately reflect the dynamic nature of world trade and value chains. The seemingly staid world of effective exchange rate weight calculations may be about to become a lot more interesting. 


\section{INTRODUCTION}

1. Assessing international competitiveness is a key interest of policy makers, although making sense of the effect of exchange rate changes on such competitiveness is often difficult. Policy makers are always interested in comparing the competitiveness of their exports against those of others. Such assessments were relatively straightforward in the two and a half decades that followed World War II - since countries generally followed a fixed exchange rate against the dollar, devaluations were normally against virtually all trade partners. Things got considerably more complicated with the advent of floating exchange rate regimes in the 1970s, when the value of major currencies started moving rapidly against each other. These developments begged the question - how to keep track of a country's competitiveness when bilateral exchange rates with competitors do not move in unison?

2. The answer to this conundrum was to calculate effective exchange rates that use the relative importance of trading partners to assess their importance in competitiveness. So, for example, the dollar is much more important than the euro in the effective exchange rate of Mexico, while the opposite is true for Sweden. Such effective exchange rates provide a summary measure of a country's competitiveness by assigning larger weights to those economies with which any given country competes more intensely. Given how concisely they summarize a complex issue, it is no surprise that real effective exchange rates have become a standard metric for measuring competitiveness. However, the indexes currently in use today have not incorporated the rise of global value chains in international trade.

3. This paper explains how and why assumptions about the nature of global value chains can have major implications for such competitiveness calculations going forward. In particular, we argue that accounting for global value chains lowers the importance of countries that export components in global value chains, which generally involve trade with close neighbors, and increases the importance of exports of final goods, which tend to go to countries that are further away. As the weight of neighboring countries linked to each other through regional supply chains fall, more weight is placed on countries further away. We also find that the distinction between the new and the traditional indexes has not had significant implications because of how key bilateral exchange rates have behaved in the past. Going forward, assessments of the relatively roles of major currencies in competitiveness calculations will become more important.

4. The remainder of this paper examines these issues in more detail. The next section discusses how new models of competitiveness incorporate global value chains and the implications for effective exchange rate weights. This is followed by an analysis of the existing evidence, including why it has been so difficult to differentiate alternative models empirically. Next, the implications for assessments of trade openness are outlined. We conclude with a discussion of the implication of global value chains for the calculations of competitiveness. 


\section{COMPETITIVENESS IN THEORY}

5. To understand the issues at stake in estimating competitiveness, it is useful to explain how conventional effective exchange rate weights are calculated. ${ }^{2}$ The approach has changed little since the late 1960s, when Paul S. Armington wrote an elegant paper in which he showed that, in a world in which goods produced by different countries were imperfect substitutes for each other, then (under some not terribly demanding assumptions) one good's competitiveness depended on the relative price of that good compared to the other goods. ${ }^{3}$ Assuming further that each country only produced one good generated the familiar effective exchange rate indices that are almost universally used today, including those produced by the BIS, ECB, Federal Reserve, the IMF, and the OECD, albeit with subtly different additional assumptions (for example on commodity trade). ${ }^{4}$

6. Like any theoretical construct, the traditional approach has limitations. As just discussed, it assumes that the exports of a country can be approximated by a single good, and that these country "goods" have the same sensitivity to changes in relative prices. Possibly even more importantly, the model assumes that all exports are final goods that are consumed in the receiving country. While this may have been a reasonable approximation at the time when the paper was written, as production chains were mainly located within countries, this assumption is much more questionable in a modern world of international value chains. In today's world, Adam Smith's pin factories are not entirely located within borders. Indeed, about a third of exports are components that are assembled into products that are then sent elsewhere for final sale (Figure 1).

7. In response, several authors have recently proposed approaches to calculating competitiveness that incorporate global value chains. ${ }^{5}$ The key innovation is that, given the possibility of international trade in components, exchange rate movements change prices of imported components as well as final goods. Effective exchange rates, which aim to keep track of the competitiveness of countries' production, thus depend on assumptions about how both producers and consumers react to changes in exchange rates.

\footnotetext{
${ }^{2}$ See Annex 1 for a more technical exposition.

${ }^{3}$ Armington (1969). See also McGuirk (1987).

${ }^{4}$ See Zanello and Desruelle (1997) and Bayoumi, Lee, and Jayanthi (2006) on the IMF, Lorentan (2005) on the Federal Reserve, Schmitz and others (2012) for the ECB, Durand, Simon and Webb (1992) for the OECD, and Turner and Van't dack (1993) and Klau and Fung (2006) for the BIS.

${ }^{5}$ See Bems and Johnson (2015), Patel, Wang, and Wei (2017), and Bayoumi, Saito, and Turunen (2013). Other analyses of exchange rates and value chains include Ahmed, Appendino, and Ruta (2016), and Cheng and others (2016). For a broader overview of the effect that GVCs have on various aspects of the world economy, including but not limited to real effective exchange rate calculations, see IMF (2013).
} 


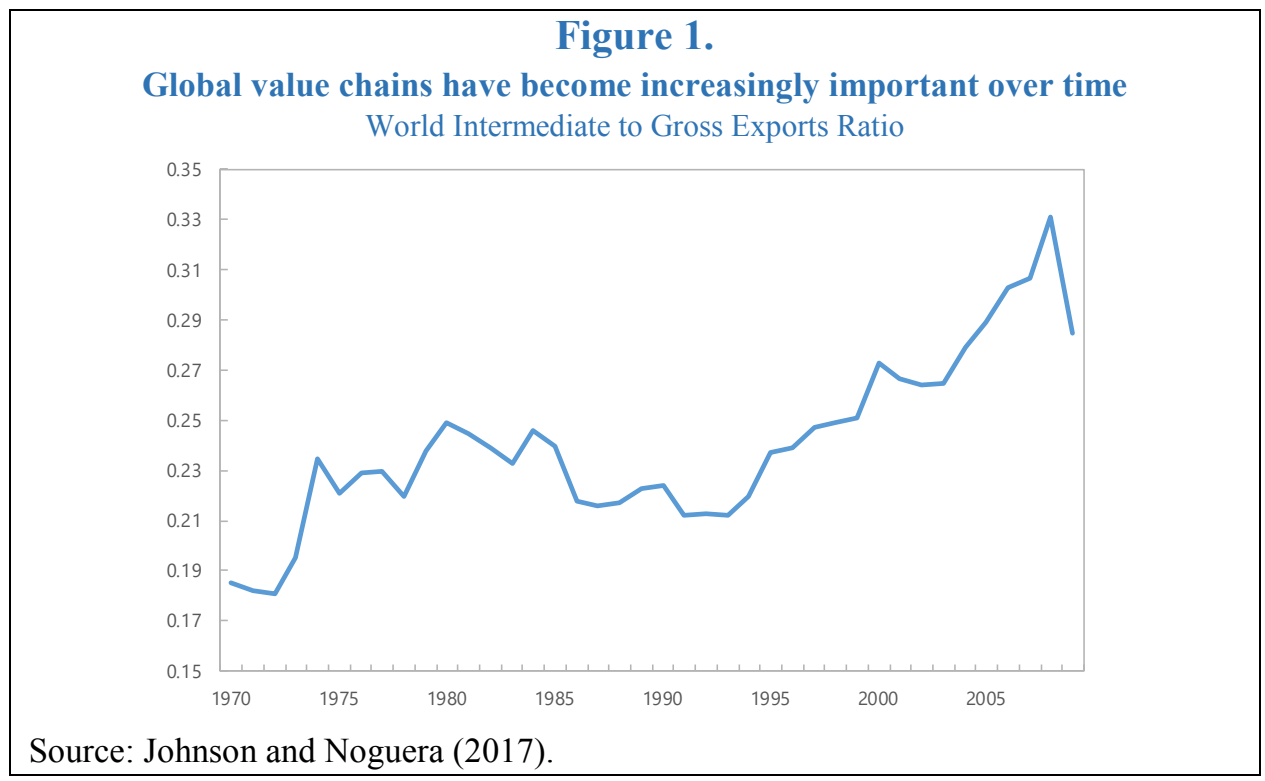

8. These modifications to the traditional model can matter a great deal for how trading partners figure into competitiveness. To see this, consider a world of three countries, where a Korean firm produces flat screens that a Chinese firm puts them into computers that are exported to the United States. Does a depreciation in the renminbi raise or lower the Korean firm's competitiveness (i.e., its exports of flat screens)? It all depends. If the United States' demand for computers is not very price sensitive (e.g. if U.S. consumers do not easily switch between Chinese and other computers) while the Chinese producers' demand for flat screens is highly price sensitive (e.g. if they are happy to switch to other flat screens), then a renminbi depreciation will lower Korean exports of flat screens, because the fall in demand from Chinese producers will dominate the rise in U.S. demand for the final computers. This is the conventional case in which a depreciation in the renminbi makes the won less competitive and hence the weight of China in this Korean firm's effective exchange rate is positive. By contrast, in the opposite case where the demand for computers in the United States is highly price sensitive while the demand for flat screens from Chinese producers is not very price sensitive, then the Korean firm's competitiveness will rise because the fillip to the U.S. demand for computers will feed back and increase demand for Korean flat screens. In this case, the depreciation of the renminbi against the dollar boosts demand for Korean flat screens and increased their competitiveness - in other words, the weight of the renminbi in the effective exchange rate of the Korean firm is negative. ${ }^{6}$

9. More formally, it is useful to distinguish three canonical cases for relationships between competitiveness and global value chains. The traditional approach assumes all trade is in final goods, and hence trade in components can be ignored. Alternatively, supply chains could be assumed to be relatively flexible, with producers being as likely to change

\footnotetext{
${ }^{6}$ In this case, a depreciation of the Korean won will also boost demand for Chinese computers by lowering the cost of flat screens, so the weight of the won in the renminbi effective exchange rate will also be negative.
} 
supplier of components as final consumers are likely to switch to a different product in response to changes in prices. As it turns out, in this case the intermediate production process is simply a chimera. The flat screens discussed above can be thought about as being directly exported from Korea to the United States. A third possibility is that inputs used in supply chains are so specific that producers will be unresponsive to changes in prices of components, a case we will denote as inflexible supply chains. ${ }^{7}$

10. Fortunately for alternative effective exchange rate weight calculations, we now have the tools to measure trade by types of goods. Researchers have linked together matrices of production across countries (called input-output tables), so that it is possible to determine if exports are used as intermediate or final goods, allowing more complex measures of competitiveness to be calculated that take account of trade in components. As an added bonus, this also allows a more accurate calculation of how open a country is to international trade. Conventional measures of trade openness include imports of components that are then put into other goods and reexported. Since gross domestic product, the standard measure of output, avoids such double counting by ignoring the buying of components - so the value added of (say) a car excludes the cost of the steel used to make it - conventional measures of exports can exceed output. Calculating value added trade by excluding intermediate imports that are put into exports makes the calculation of trade consistent with the rest of gross domestic product. Input-output tables make it possible to compute such "value added" trade.

11. The relevant price index for calculating competitiveness also changes once trade in components are accounted for. While the focus of this note is on the more complex issue of country weights, allowing for intermediate-input trade also means that final-demand prices are not the only ones that matter. Under the traditional assumption of no trade in components (and no investment), the use of consumer price indexes to construct real effective exchange rates is entirely justified. As argued by Bems and Johnson (2017), in the presence of trade in components, the relevant price is it is the price of real value added-i.e. GDP deflators.

\section{Competitiveness in Practice}

12. To show the importance of these issues, Figure 2 shows the relative weights of China, the United States, and Germany in the effective exchange rate of Korea in 2011 for our different assumptions: ${ }^{8}$ the traditional model, the flexible supply chains model, and the inflexible supply chains model (all calculated by Bems and Johnson, 2017). The traditional model, which assumes all goods are final goods, gives China a weight of 0.23 in

\footnotetext{
${ }^{7}$ In the terminology proposed by Bems and Johnson (2017), the flexible supply chains assumption is denoted as value-added real effective exchange rate, whereas inflexible supply chains corresponds to their Leontief real effective exchange rate. The traditional model is often referred to as the Armington model.

${ }^{8}$ We focus on China, the United States, and Germany since these are the countries at the center of the Asian, European, and North American supply chains, respectively.
} 
the Korean real effective exchange rate, while the United States has a weight of 0.10 and Germany a weight of 0.04 . The difference in these weights shrinks under flexible supply chains - the weight of China in Korea's effective exchange rate falls to 0.20 and that of the United States and Germany rise to 0.13 and 0.045 , respectively. This shrinkage occurs because components produced in Korea and shipped to China but then incorporated into goods bound for the United States (Germany) are now counted as exports to the United States (Germany) rather than to China.

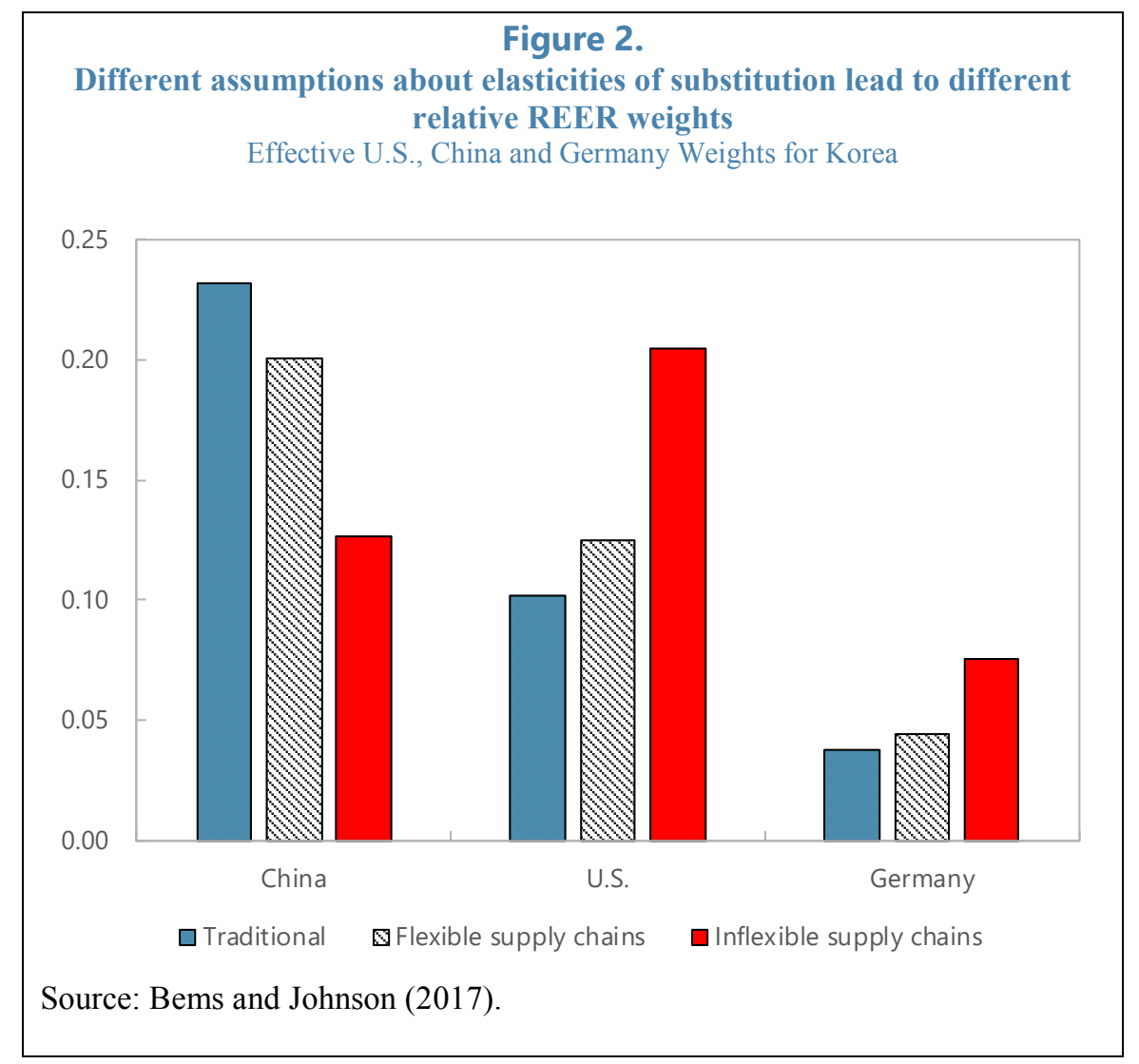

\section{The relative importance of China versus the United States or Germany in} Korean competitiveness changes much more dramatically if supply chains are inflexible. In this case, the weight of China in Korea's effective exchange rate falls to just 0.13 while the weight of the United States and Germany rise to 0.20 and 0.08 , respectively. In other words, under this assumption the United States is now more important for Korea's competitiveness than China, and Germany is not so far behind China. This happens because in a world of inflexible supply chains a depreciation of the renminbi against the dollar has ambiguous effects on Korean exports to the United States (Germany). While it lowers Korean exports of final goods as these compete with Chinese goods in the U.S. (German) market, it increases sales of components such as flat screen that are incorporated into Chinese 
final goods and then shipped to the United States (Germany). This ambiguity reduces the importance of China in Korea's competitiveness. ${ }^{9}$

14. The basic intuition holds more generally. Accounting for supply chains implies that, relative to the traditional approach that ignores trade in components, new competitiveness measures place less weight on countries that are in global value chains and more weight on other countries (Figure 3, top panel). ${ }^{10}$ Since component trade takes place disproportionately more between countries in the same region, failing to recognize these production linkages results in competitiveness calculations that overestimate the importance of neighboring countries and underestimates the importance of countries that are further away. This effect is larger if supply chains are less flexible (Figure 3, bottom panel).

\section{The result is an increase in the global importance of countries relatively more} involved in final-demand trade. For example, the simple average of the renminbi effective exchange rate weights in those G20 countries for which data are available falls from 13 to 12 percent for China while rising from 16 percent to 20 percent for the United States.

\footnotetext{
${ }^{9}$ Similar, if less dramatic, changes in importance occur in other supply chains once trade in components is taken into account in other supply chains. So, for example, the role of Germany in Hungary's competitiveness diminishes while that of China and the United States are boosted; similarly, for Canadian competitiveness, the role of the United States diminishes and the importance of China and Germany rises.

10 The countries included in each regional supply chain are determined by data availability in the input-output databased used by Bems and Johnson (2017).
} 
Figure 3.

A Smaller World: Countries afar matter more when global value chains are accounted for

Change in effective exchange rate weights
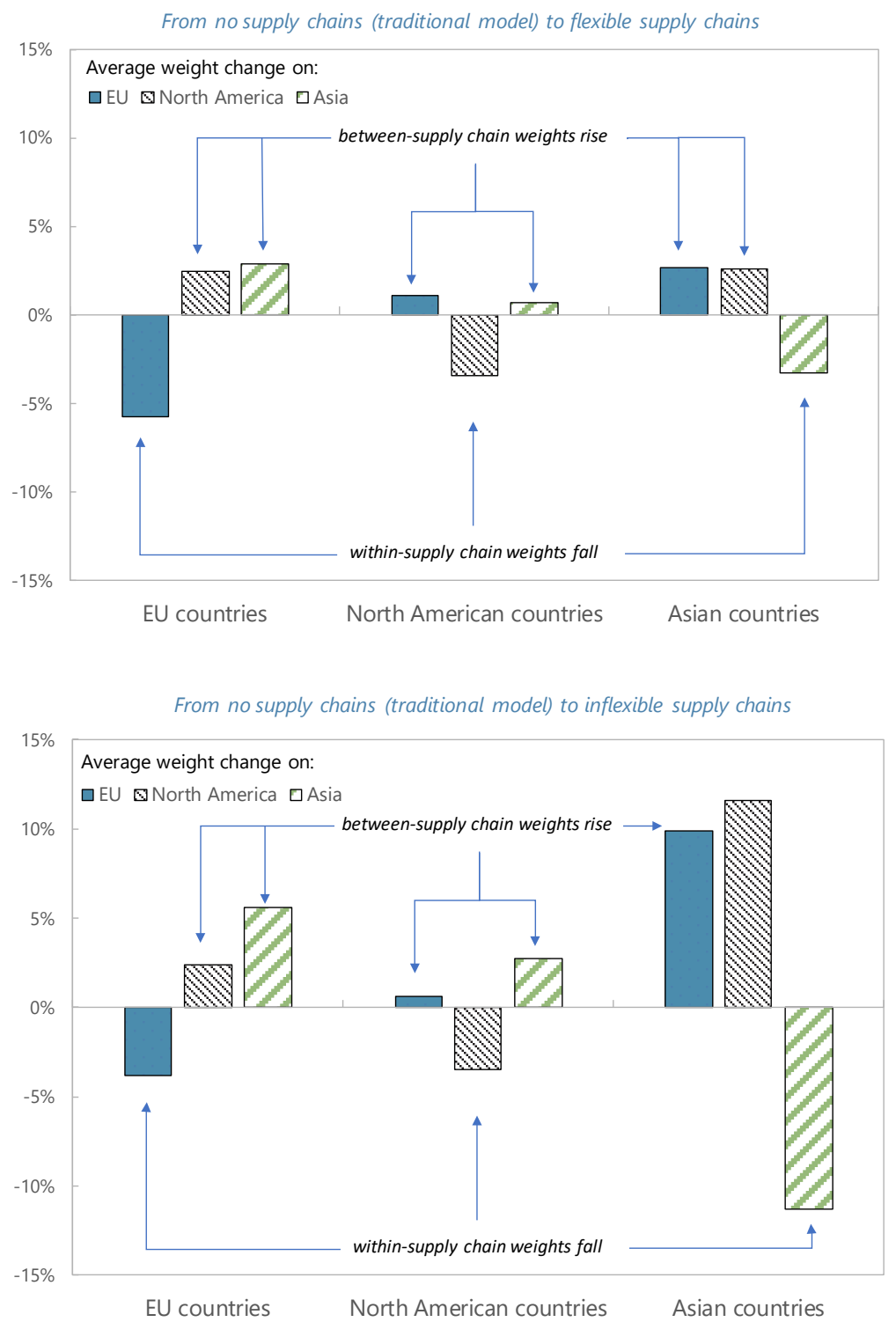

Source: Bems and Johnson (2017), and authors' calculations.

\section{EMPIRICAL COMPARISONS}

16. The question that naturally arises is which assumption about competitiveness best characterizes the world. An obvious way of potentially examining this issue is to compare the relative empirical performance of measures of international competitiveness using different assumptions. As this section shows, however, it is essentially impossible to 
differentiate the past performance of these alternative measures. The similarity of past competitiveness indicators reflects two underlying trends. First, the importance of trade in components has been rising over time. As can be seen in Figure 1, there has been a steady increase in the importance of trade in components since the mid-1990s. In other words, global value chains are a relatively recent phenomenon. Second, while the Asian, European, and North American supply chains have become more important, quantitatively the effects are dominated by the impact of the Asian supply chain. This can be illustrated by comparing the shift in the weight of the United States, China, and Euro area countries in 2011 across G20 countries with available data as a result of switching from using the traditional model, that ignores global supply chains, to assuming inflexible supply chains. Shifts in the weight of the renminbi and the dollar between the traditional and inflexible production assumptions have a correlation of -0.6 , implying that a decrease in (say) the weight on the renminbi is generally associated with an increase in the weight of the dollar. By contrast, changes in the weights of the dollar and the euro have a correlation of over 0.5 , so increases in the importance of the dollar tend to be accompanied by increases in the weight on the Euro.

\section{The fact that lower weights for the renminbi tend to be offset by higher weights on the dollar helps to explain why it is difficult to empirically distinguish between the different models of effective exchange rates weights. Because the renminbi has been} closely linked to the dollar, the paths of the effective exchange rates that account for GVCs are not very different from those using traditional weights. The case of Korea is illustrative. While the weight on the dollar in Korea's effective exchange rate in 2011 rises by 10 percentage points using inflexible supply chain assumptions versus traditional ones, the renminbi's weight falls by around the same amount. Hence, the sum of the two weights is very similar. Since the dollar and the renminbi have tended to appreciate and depreciate against other currencies in tandem, the switch in weights has little impact on the estimated real effective exchange rate for Korea. As can be seen in Figure 4, the similarity across different weighting schemes of the sum of the Chinese and U.S. weights is not limited to Korea. 
Figure 4.

Lower renminbi weights are largely offset by higher dollar weights Sum of US and China Weights over different REER Measures 2011

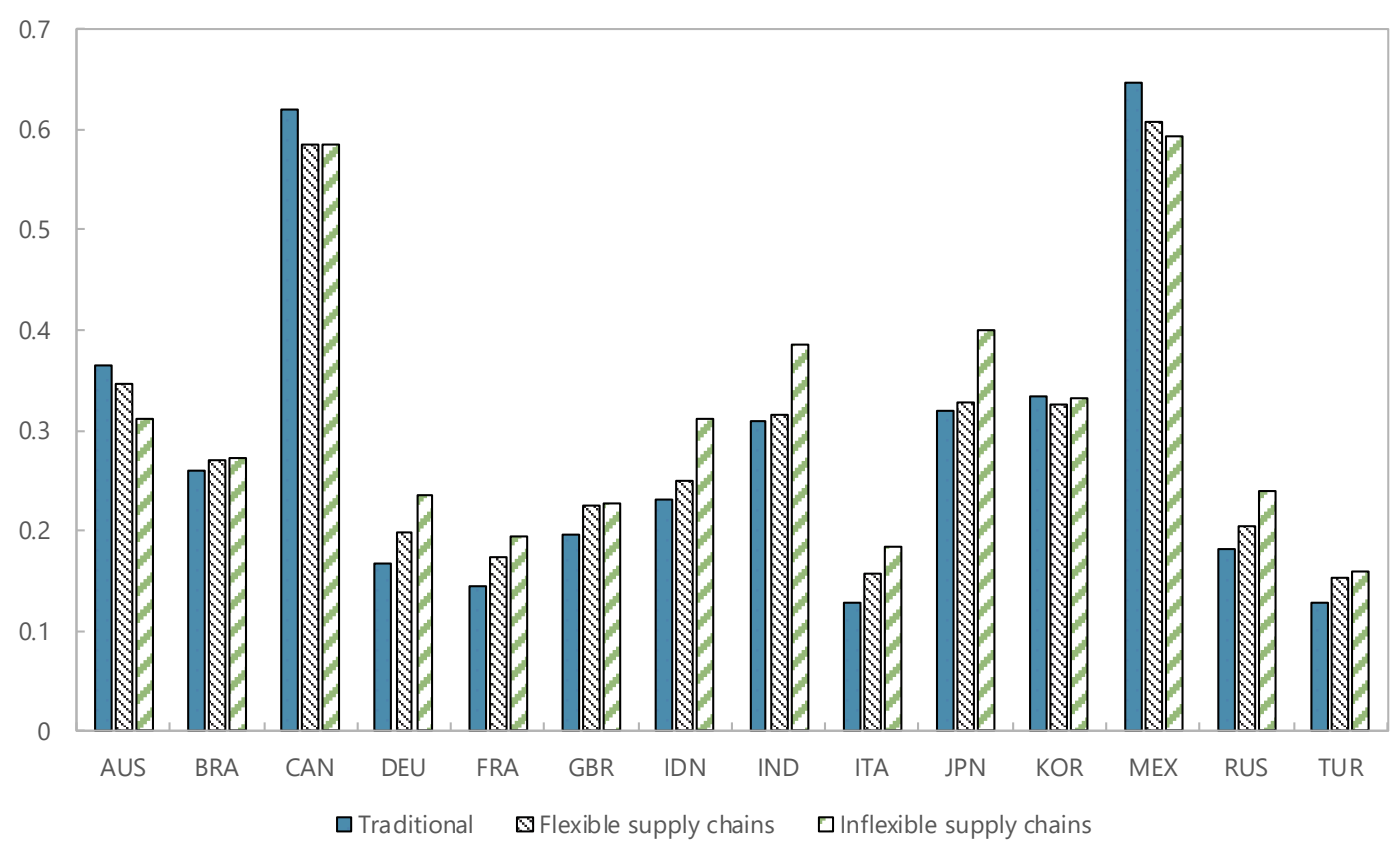

Source: Bems and Johnson (2017).

18. By contrast, as the dollar floats against the euro, appreciations in the dollar tend to be accompanied by depreciations in the euro. But since increases in the weight of the dollar caused by the switch to inflexible production weights tend to be also accompanied by increases in the weight on the euro, these effects also tend to cancel out in competitiveness calculations. To illustrate the similarity of effective exchange rates using different weighting schemes, Table 1 reports the correlations between Bems and Johnson's estimates of real effective exchange rates using traditional weights, flexible supply chain weights, and inflexible supply chain weights. As the first column shows, the average correlation over 1980-2011 between the traditional and inflexible supply chains real effective exchange rates is $0.9 .{ }^{11}$ The correlation between the flexible and inflexible supply chain indexes is even higher, with an average correlation of 0.994 . Indeed, the correlations are even higher for Korea and Australia, countries where the weight of China and the U.S. differ greatly across the two approaches. In Annex 2, we show that these cursory observations also show up in a deeper analysis of trade elasticities. Using historical data, the elasticities of imports and

\footnotetext{
${ }^{11}$ The 1980-2011 data were constructed by extending the Bems and Johnson calculations for 1995-2011 back using an earlier data set which covers 1980-2009. Russia is not included in the earlier data set and hence in the calculations.
} 
exports to real effective exchange rate movements do not change in any significant way when incorporating global value chains considerations in the partner weights. ${ }^{12}$

Table 1. Correlations of Different Real Effective Exchange Rate Indexes, 1980-2011

\begin{tabular}{lcc} 
& $\begin{array}{c}\text { Armington vs. } \\
\text { Leontief production }\end{array}$ & $\begin{array}{c}\text { Value Added vs. } \\
\text { Leontief production }\end{array}$ \\
\hline \hline AUS & 0.986 & 0.997 \\
BRA & 0.855 & 0.999 \\
CAN & 0.976 & 0.993 \\
CHN & 0.988 & 0.999 \\
DEU & 0.733 & 0.992 \\
FRA & 0.965 & 0.982 \\
GBR & 0.919 & 0.997 \\
IDN & 0.908 & 0.997 \\
IND & 0.993 & 0.999 \\
ITA & 0.866 & 0.990 \\
JPN & 0.924 & 0.997 \\
KOR & 0.785 & 0.989 \\
MEX & 0.947 & 0.999 \\
TUR & 0.719 & 0.985 \\
USA & 0.943 & 0.997 \\
Average & 0.900 & 0.994 \\
\hline
\end{tabular}

19. As all major currencies move to greater flexibility vis-à-vis each other, differing assumptions about global supply chains will imply quite different results for competitiveness. The results in this section explain why it is so difficult to use past data to empirically differentiate between real effective exchange rate created using different assumptions. However, given the large differences in the current importance of (say) the United States and China in Korean competitiveness implied by differing assumptions about supply chains, it will be important to take a view on which assumption is the most plausible as the renminbi becomes more flexible against the dollar.

\section{Production and Final Demand Elasticities}

20. The key difference between the flexible and inflexible global value chain models is the relative elasticity of substitution of components in the production process. Bems and Johnson (2015) argue that the crucial parameter for calculating weights is the relative price sensitivity of components in production compared to final goods. This suggests that actual outcomes for short-term movements in exchange rates are likely to lie somewhere between the flexible model (where the ratio of the two elasticities is one) and the inflexible

\footnotetext{
12 This result is not inconsistent with the finding that, over time, trade in some sectors may have become less sensitive to exchange rate movements (e.g. IMF, 2015, and Ahmed et al., 2017). What we find here is that, for any given time period, estimated trade elasticities are virtually the same regardless of the way competitiveness is measured.
} 
model (where the ratio is zero). The issue is which assumption is a better approximation to reality.

21. To the best of our knowledge, no paper has tried to estimate and compare production and final demand elasticities of substitution, but the evidence suggests the elasticity in production is likely low. While it is implausible that the elasticity of substitution of components in production is literally zero, which implies that producers always use the same components regardless of price, the elasticity of substitution is likely low within supply chains. This is because there needs to be a close relationship between producers and their component suppliers as producers ask their suppliers to provide very specific goods (think of screens for iPads). Suppliers are unlikely to go to the expense of setting up such specific production processes without some assurance that the producer will continue to buy their product.

\section{Various pieces of indirect evidence support the notion of low elasticities of} substitution within supply chains. Low supply-chain elasticities help explain why business cycles are more synchronized between countries that participate in the same value chains (Burstein et al., 2008); why trade in components plays a significant role in propagating shocks, whereas trade in final goods does not (de Soyres, 2017); and why for U.S. firms' every $\$ 1$ of lost sales at the supplier level due to a natural disaster leads to $\$ 2.40$ loss of downstream sales (Barrot and Sauvagnat, 2016).

\section{Direct estimates of substitutability across intermediate inputs also strongly} support a low degree of flexibility at business-cycle frequencies. Using U.S. input-output data covering 1997-2013, Atalay (2017) finds production elasticities that are consistently below 0.2. Similarly, based on the supply-chain response to the 2011 Japanese earthquake, Boehm et al. (forthcoming) find that the elasticity of substitution across material (i.e. nonlabor, non-capital) inputs for Japanese multinationals is 0.2 .

\section{For our purposes, what matters is how these low production elasticities compare} with final-demand elasticities. Broda and Weinstein (2006) estimate consumers' elasticities of substitution at various levels of disaggregation. While their estimates vary depending on the level of disaggregation - e.g. the elasticity of substitution between different types of goods is generally smaller than that between different varieties of the same good-none of their estimates falls below 1.0. ${ }^{13}$ Using standard classifications, their estimates also suggest that elasticities on intermediate goods in the U.S. are, on average, lower than elasticities on

\footnotetext{
${ }^{13}$ In their more-recent sample (1990-2001), the mean estimate across all sectors is no lower than 4.0 (see Table IV in Broda and Weinstein, 2006). The sector with the smallest elasticity (footwear, using a 1972-1988 sample) has an estimated elasticity of 1.2 (Table V).
} 
final-demand goods (Figure 5). ${ }^{14}$ In all, the evidence strongly suggests that, at least in the short- to medium-term, production elasticities are likely much smaller than final-demand elasticities. This suggests that the inflexible global value chain model may be a relatively good approximation to reality, with the implied fall in importance of countries participating in value chains in calculations of competitiveness. ${ }^{15}$

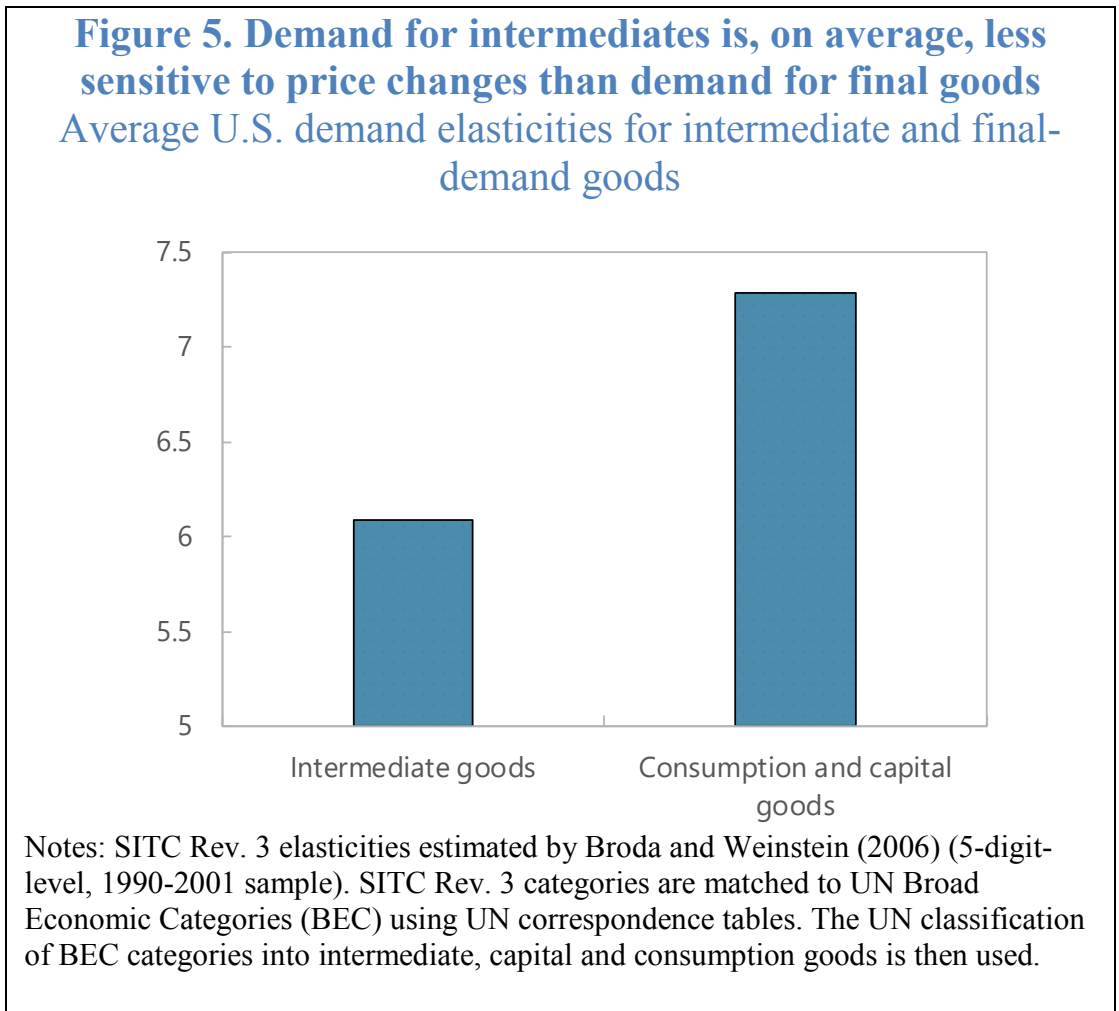

\section{At the other end of the spectrum, competitiveness calculations should also deal} with goods with extremely high elasticities of substitution, such as raw materials. While the model of differentiated goods works for complex manufactured goods of the type often exported by Korea or Japan, it does not work for raw materials such as coal that is essentially identical across countries. This high substitutability implies that there is a single global price for coal that depends on global demand and supply conditions and hence that the

\footnotetext{
${ }^{14}$ Intermediates in Figure 5 include commoditized goods, such as petroleum and its derivatives. These goods, which as discussed below warrant a separate treatment, tend to have high elasticities of substitution and therefore bias upwards the average elasticity of intermediates that is relevant for our purposes.

15 The rise in importance of the dollar in real effective exchange rates is consistent with recent work that argues for an added importance of the dollar exchange rate due to invoicing (Boz, Gopinath and Plagborg-Møller, 2018). The dollar dominance in that case rests on the degree to which producers do not adjust their prices. Existing evidence to that end finds that the relevant horizons are relatively short (e.g. the median frequency of price adjustment ranges between 10 to 13 months; Table 1 in Gopinath and Rigobon, 2008). Beyond these time windows, the GVC considerations discussed here appear more relevant.
} 
competitiveness of Australian coal exports is linked with all coal exporters and importers, even if most Australian coal goes to China because geographic proximity generates lower transport costs. Indeed, the IMF effective exchange rate methodology assumes global competition for commodity exports.

\section{The same approach could also be applied to "commoditized" manufactured} goods, such as bulk steel or basic memory chips. These are standard components that are essentially slotted into products at the appropriate moment, and where the exact source of supply is not important - one standard computer chip is very much like another. As in the case of oil or coal, or copper or aluminum, the elasticity of substitution in such markets is high, leading to a single global price in which trade patterns are dominated by costs of transportation. This implies a two-tier system for analyzing intermediate manufactured goods. Those that are "commoditized" and should be treated as being part of a single global market, and those that are "custom-made" and should be treated as differentiated goods.

\section{Dynamic EfFective Exchange Rate Weights}

\section{The rise in importance of China in global trade also underlines the importance} of using dynamic effective exchange rates over time. As late as 1999, when the euro area was formed, China was no more than a bit player in the global trading system. Its average weight in other G20 countries was less than 4 percentage points regardless of the model used, compared to weights of over 20 percentage points for the dollar and the euro. Given the marginal importance of China in the global trading system in 1999, the negative correlation between the changes in US and China weights (which already existed in 1999) was much less important than the positive correlation between US and Euro area weights (which was also apparent in 1999).

\section{Over the intervening period, the role of the dollar and the Euro has shrunk} while that of the renminbi increased by over three-fold. By 2011, as discussed earlier, the importance of the renminbi was not much lower than the dollar or the euro even using the inflexible production model that implies relatively low weights on members of supply chains. The increased importance of China reflects both its growth and the opening of the economy after entry to the WTO in 2001. This underlines the importance of using dynamic effective exchange rate weights, for example by relying on chain indices with weights that are updated every three years..

\section{Trade Openness and Global Value Chains}

\section{Focusing on global value chains also has implications for how to measure} openness to trade across countries. ${ }^{16}$ For the traditional model, the correct measure of trade

\footnotetext{
${ }^{16}$ Trade openness refers here to the value of trade in ratio to countries' output. As such, it is a reflection not only of policies, but also a host of non-policy factors, such as countries' size, geographical location, cultural barriers that affect trade, etc.
} 
openness is gross trade as a ratio to gross output, since all exports and imports are treated as final goods and hence are equally important. For the models that incorporate global value chains, on the other hand, trade openness should be measured using only exports and imports of value added, in ratio to GDP. Using this assumption implies that countries that include a high proportion of imported components in their exports will appear relatively less open than countries whose exports contain fewer imported goods. Indeed, the dangers of using gross trade have long been recognized, which is why in some extreme cases - such as Hong Kong SAR — an adjustment is normally made for reexports. However, such changes are seldom made on a consistent basis across all countries.

30. Figure 6 shows the implications of switching from gross trade to value added trade on the relative openness of $\mathbf{G 2 0}$ countries. As expected, switching to value added trade lowers the relative openness to trade for countries that are heavily involved in value chains. Relative openness falls significantly in Korea, China and Mexico, along with smaller falls for most members of the European supply chain. This is offset by rises in relative openness in many commodity-exporting countries not closely associated with global value chains (Argentina, Australia, Brazil, Indonesia, and Russia) as well as Japan (which has little processing trade) and the United States (which has high consumption compared to output).

\section{These calculations of openness are the domestic counterparts of the earlier} analysis on changing exchange rate weights associated with global value chains. With the new metric, the degree of relative openness of countries more heavily involved in supply chains, such as Germany and China, is not as high as under traditional metrics. By contrast, it increases the relative role of trade in the US economy. These changes are the domestic counterpart to the shift in the importance of these countries in other countries' real effective exchange rate weights.

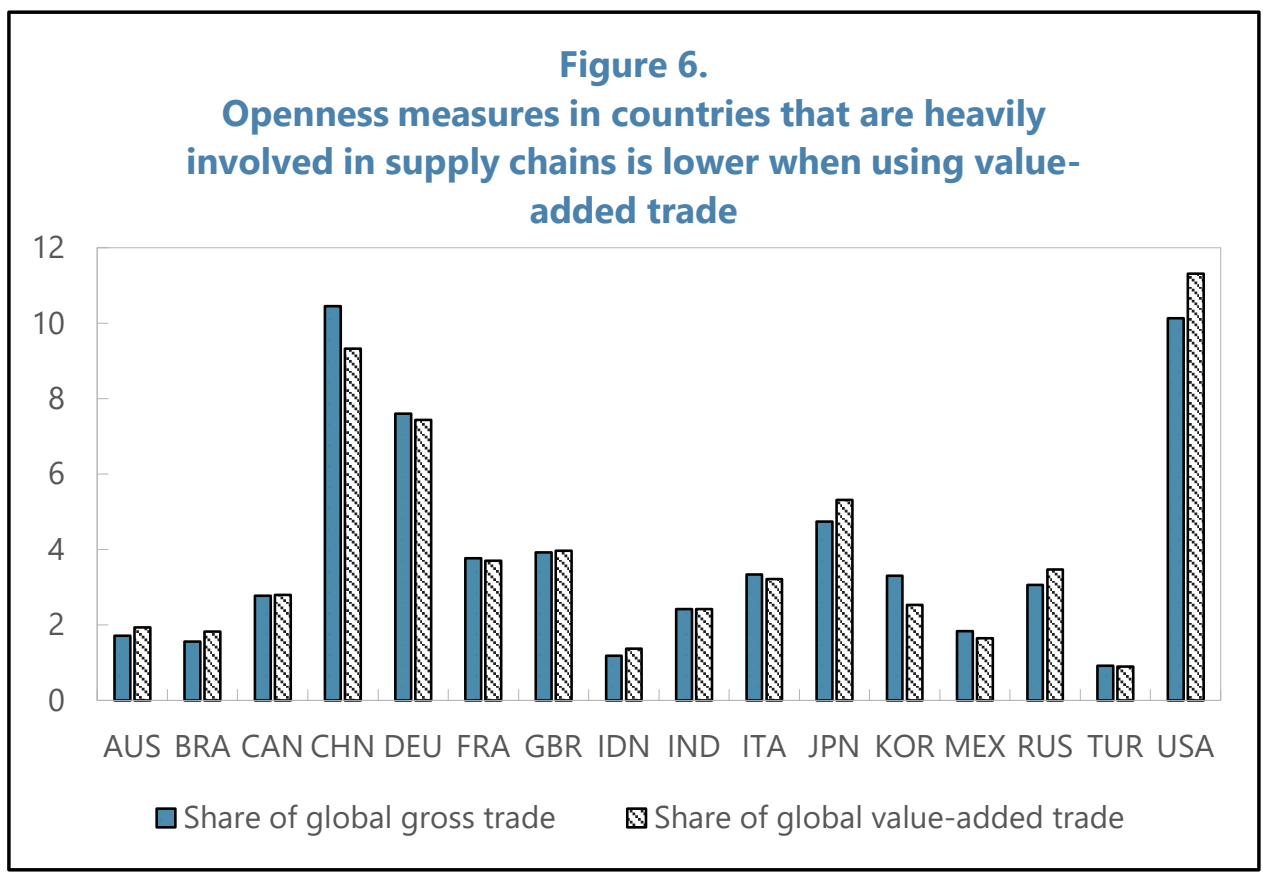




\section{Conclusions}

32. The increasing importance of international value chains is a major trend in the trade landscape. ${ }^{17}$ Unfortunately, the approach commonly used for calculating effective exchange rates has not caught up. All of the major effective exchange rates used by policy makers assume that all trade is in final goods. While this was never an accurate assumption, it is becoming steadily less tenable over time. The key question, however, is whether switching to a better and more accurate approach would make a significant difference to calculated real effective exchange rates. In other words, whether the added theoretical and computational complexity coming from accounting for global value chains is worth the trouble, or if the simpler approach currently being used provides a reasonable approximation to reality.

\section{The answer from this analysis is that accounting for global value chains will} likely matter for competitiveness measures going forward. Even in the case where the global value chains are flexible, current effective exchange rate weights and calculations of openness overstate the role of neighboring countries and underestimate the role of countries that lie further away from a country's regional supply chain. In the more likely case that global value chains are relatively inflexible, then taking account of global value chains creates an even larger switch in effective exchange rate weights away from nearby countries toward countries in other parts of the world.

\section{The changes in weights as a result of accounting for supply chains have been} difficult to identify in overall competitiveness measures due to the nature of currency

movements. Reductions in the weight of China in effective exchange rate indexes tend to be accompanied by increases in the weight of the United States. But, in the past, the renminbi has fluctuated relatively little against the dollar, thus making it difficult to pick up this trend in the data as alternative assumptions about real effective exchange rate have produced similar results. By contrast, as the dollar floated against the euro, appreciations in the dollar tended to be accompanied by depreciations in the euro. But since increases in the weight of the dollar tend to be also accompanied by increases in the weight on the euro, these effects also tend to cancel out in effective exchange rate calculations. Over the future, however, as all major currencies move less in tandem, the differences in weights will matter.

\section{This suggests that it is important to soon get a better handle on the appropriate}

assumptions. This will involve examining how the elasticity of substitution for components used in supply chains compares with the elasticity of demand for final products, and what this implies for competitiveness weights. In addition, there are clearly other types of components which are standardized and simply slotted into final goods - such as basic silicon chips. Since these are standard components, the elasticity of substitution is high and

\footnotetext{
${ }^{17}$ See, for example, IMF (2016) for a discussion of the role of global supply chains in explaining the rate of growth of trade over time.
} 
the price is set by global supply and demand, very much like traditional commodities such as coal or copper. This suggests that the adjustments already made, at least in the IMF real effective exchange rate calculations, for highly traded commodities that assumes that they compete with all producers and consumers of that good, needs to be extended to certain types of industrial goods.

\section{The changing nature of the global economy is also putting a premium on}

updating effective exchange rate weights. In addition to changes in value chains, rapid increases in the importance of emerging markets in global trade underlines the importance of regularly refreshing effective exchange rate weights. Effective exchange rate indexes should become as dynamic as the global economy.

\section{This implies a three-fold agenda for future work on real effective exchange rates.}

First, determining the relative substitutability of differentiated intermediate goods in production versus final demand at different horizons, also contemplating the possibility that different supply-chain assumptions may be more relevant at different time horizons; next, examining how to split "commoditized" goods from highly differentiated goods; and, finally, providing regular updates of weights. The seemingly staid world of effective exchange rate weight calculations may be about to become a lot more interesting. 


\section{AnNeX 1. The Theory of Real Effective EXChange Rates}

38. Modern theories of real effective exchange rates all rely on constant elasticity of substitution (CES) functions. Consider the basic CES demand for goods used by the traditional REER model based on the work by Armington:

$$
U_{t}=\left(\sum_{i=1}^{n}\left(\frac{\omega_{i t}}{\omega_{t}}\right)^{1 / \rho} C_{i t}^{(\rho-1) / \rho}\right)^{\rho /(\rho-1)}
$$

where $U_{t}$ is utility, $\omega_{i t}$ are weights that sum to $\omega_{t}, C_{i t}$ is consumption, and $\rho$ is the elasticity of substitution. This functional form is attractive for effective exchange rate calculations because it allows goods to be aggregated into an "ideal" single composite good, so that the final demand for any good can be expressed as a function of the relative price of that good versus the (composite) price of the composite good. Hence:

$$
C_{i t}=A_{i t} C_{t}\left(\frac{P_{i t}}{P_{t}}\right)^{\rho}
$$

where $\mathrm{C}_{\mathrm{it}}$ is the consumption of the final good, $\mathrm{A}_{\mathrm{it}}$ is an (approximate) constant, $\mathrm{C}_{\mathrm{t}}$ is the composite good, and $\mathrm{P}_{\mathrm{it}} / \mathrm{P}_{\mathrm{t}}$ is the relative prices of the final good compared to the price of the composite good.

39. The ability to aggregate across goods allows CES functions to be nested. This means that the model can look at the consequences of imports and exports of intermediate goods used in production as well as the final goods assumed by Armington. For example, in the model of Bems and Johnson (2017) there are three nested CES functions. Conceptually, firms first put together intermediate goods, which they next combine with domestic value added (labor, capital, and land) to create goods. These firms then either send their good on to be used in further production or to be consumed as final goods. This leads to a system in which the demand for a good depends on three elasticities of substitution, that across intermediate goods $(\sigma)$, that between intermediate goods and domestic value added $(\gamma)$, and that between final consumption goods $(\rho)$. It is the interaction between these three elasticities than determine the real effective exchange rate weights of goods across countries.

40. In practice, it turns out the that the elasticity of substitution between the aggregate intermediate good and domestic value added $(\gamma)$ plays a relatively minor role in the calculations. Consequently, when calculating alternative effective exchange rate weights, Bems and Johnson always set it equal to the elasticity of substitution across intermediate goods $(\sigma)$. To illustrate the impact of different assumptions about the elasticities on production of intermediate goods and on final demand, Bems and Johnson report the effective exchange rate weights implied by three sets of assumptions on the elasticities of substitution, with the parameters designed to create similar sensitivities of aggregate trade to changes in exchange rates. The first calculation assumes that the elasticities of substitution 
for demand and production are all set to unity $(\sigma=\gamma=\rho=1)$, a set of assumptions we here denote as 'flexible supply chains'. ${ }^{18}$ The next calculation assumes that there is no possibility to substitute within the production process, while the elasticity of substitution for final goods is three $(\sigma=\gamma=0 ; \rho=3)$ - the case of 'inflexible supply chains' ${ }^{19}$

\section{The flexible-supply-chains assumption - in which elasticities in production and} demand are the same - produces a model with similar properties to the traditional model, but where the weights "see through" the value chain to goods' ultimate destination. So, to take the example of Korean flat screens discussed earlier, while in the traditional model the assumption would be that the flat screens were consumed in China because it assumes all goods are final goods, in this version of the model the flat screens are treated as if they were directly exported from Korea to the United States (see Table A1 for a summary of the different cases). The fact that the flat screens are incorporated into Chinese computers along the way makes no difference. This is often termed "trade in tasks", on the logic that a good is an amalgam of components ("tasks") and that in this version of the model all that matters is the initial origin of the components which are incorporated in the final goods. Because the flat Korean screens are treated as a direct export from Korea to the United States, all that matters for the demand for flat screens is the dollar-won exchange rate. Any changes in the renminbi against either the won or the dollar are irrelevant and have no impact on the demand for Korean flat screens.

\section{The second assumption - in which the demand for intermediate goods is} completely price insensitive - produces a radically different result. In this a case, it is the demand for Chinese computers in the US that determines the demand for Korean flat screens since the Leontief production function means that Chinese producers use the same amount of Korean flat screens in each computer regardless of the price. As a result, the demand for Korea flat screens depends mainly on the renminbi-dollar rate and only a little bit on the won-dollar rate. This is because what matters is the price of the entire Chinese computer in the US market. If the renminbi depreciates against the dollar but the won stays unchanged against the dollar then the demand for flat screens rises since Chinese computers are cheaper. In effect, China has a negative weight in the Korean exchange rate since a depreciation of the renminbi increases demand for flat screens. On the other hand, if the won depreciates against the dollar but the renminbi does not, there is only a small increase in demand for flat screens (the depreciation of the won against the dollar lowers the cost of the flat screens in the US market, modestly lowering their price and increasing demand for Chinese computers).

\footnotetext{
${ }^{18}$ An elasticity of one is often assumed as it makes the nominal amount spent on a good invariant to its prices, which simplifies the calculation of weights of different goods in demand and production.

${ }^{19}$ For the derivation of the weights that account for intermediates, see Section II in Bems and Johnson (2017). The general REER formula is given by equation (16) (ibid.); the value-added ('flexible supply chains') REER is given in equation (17), whereas the weights in the Leontief ('inflexible supply chains') case are given at the end of p. 57.
} 
Table A1. Different Assumptions Can Lead to Qualitatively Different Results based on illustrative example discussed in the text

\begin{tabular}{lccccc} 
& \multicolumn{2}{c}{ Elasticities } & & \multicolumn{2}{c}{ Illustrative flat-screens example } \\
\cline { 2 - 3 } Effective exchange rate & Final demand & Production & & $\begin{array}{c}\text { Effect on Korea's } \\
\text { competitiveness of RMB } \\
\text { depreciation }\end{array}$ & Explanation \\
\hline \hline Traditional & $>0$ & N/A & & Worsens & Because only RMB/WON exchange rate matter: \\
Flexible supply chains & 1 & 1 & & No change & Competitiveness is orthogonal to changes in Rr \\
Inflexible supply chains & $>0$ & 0 & & Improves & Because only RMB/USD exchange rate matters \\
\hline
\end{tabular}




\title{
AnNeX 2. Estimated Exchange Rate Elasticities Using Different Real EFFECTIVE EXCHANGE RATES Model
}

\begin{abstract}
43. This section shows estimation results for import and export models by country using a simple log-linear specification. For each country REER-trade pair, we check if the residual of the regression in levels is stationary. If so, the model is estimated in levels; otherwise it is estimated in first differences. ${ }^{20}$ Most countries in our sample show cointegration in the flexible-supply-chains (inflexible-supply-chains) real effective exchange rate-real imports relation, and in the equivalent export relation. Most of the data span 1970 to 2011. The equation for imports includes real domestic demand (interacted with a GFC dummy), a non-fuel price index, an oil price index, and a time trend. The controls in the exports equation are: real foreign demand (also interacted with a GFC dummy), real unit labor costs, a non-fuel price index, an oil price index, and a time trend. See IMF (2015) for variable definitions. Results reported here correspond to G20 economies with at least 25 years of data. The findings are qualitatively identical for non-G20 countries that meet this minimum data requirement; these additional results are available upon request.
\end{abstract}

44. By and large, import elasticities to different REER measures appear statistically indistinguishable. Figure 6 reports two sets of comparisons between import elasticity estimates. The first set of comparisons contrast the elasticity of imports estimated using the flexible-supply-chains real effective exchange rate and the traditional real effective exchange rate. The estimates are statistically indistinguishable from one another. The comparison between traditional REER elasticities and inflexible-supply-chain REER elasticities yields the same results.

\section{Export elasticities also appear insensitive to the REER measure used. Figure 7} shows the comparison of export elasticities using different REER measures. The elasticity of exports to the traditional real effective exchange rate is very similar to the elasticity from the flexible and inflexible supply chains REERs, with any small differences being statistically insignificant.

46. The findings are robust to alternative specifications. Wherever cointegration was found, the figure reports long-run elasticities. In those cases, we also compared short-run elasticities in an error-correction model, and they also look statistically indistinguishable from one another as the REER measure is changed. To account for the possibility that trade variables exhibit a stochastic trend but the real exchange rate measures do not, we have also estimated the model with trade variables in first differences and the real exchange rate in levels. The results are robust to this alternative specification. As another robustness check, we also estimated the responses of import and export prices to REER changes for the

\footnotetext{
${ }^{20}$ We are very grateful to Weicheng Lian for sharing the data and codes used in IMF (2015). Note that while IMF (2015) estimates four set of equations (from REER to import/export prices, and from import/export prices to trade volumes), here we estimate only two (from REER to trade volumes).
} 
different REER measures (as in the first two equations in IMF, 2015). The conclusions reached under this alternative specification are the same as those described above.

Figure A1.

Import and export elasticities are statistically indistinguishable between different REER measures Import elasticities with different REER measures

Traditional (Armington), Flexible Supply Chains (VAREER) and Inflexible Supply Chains (Leontief Production)
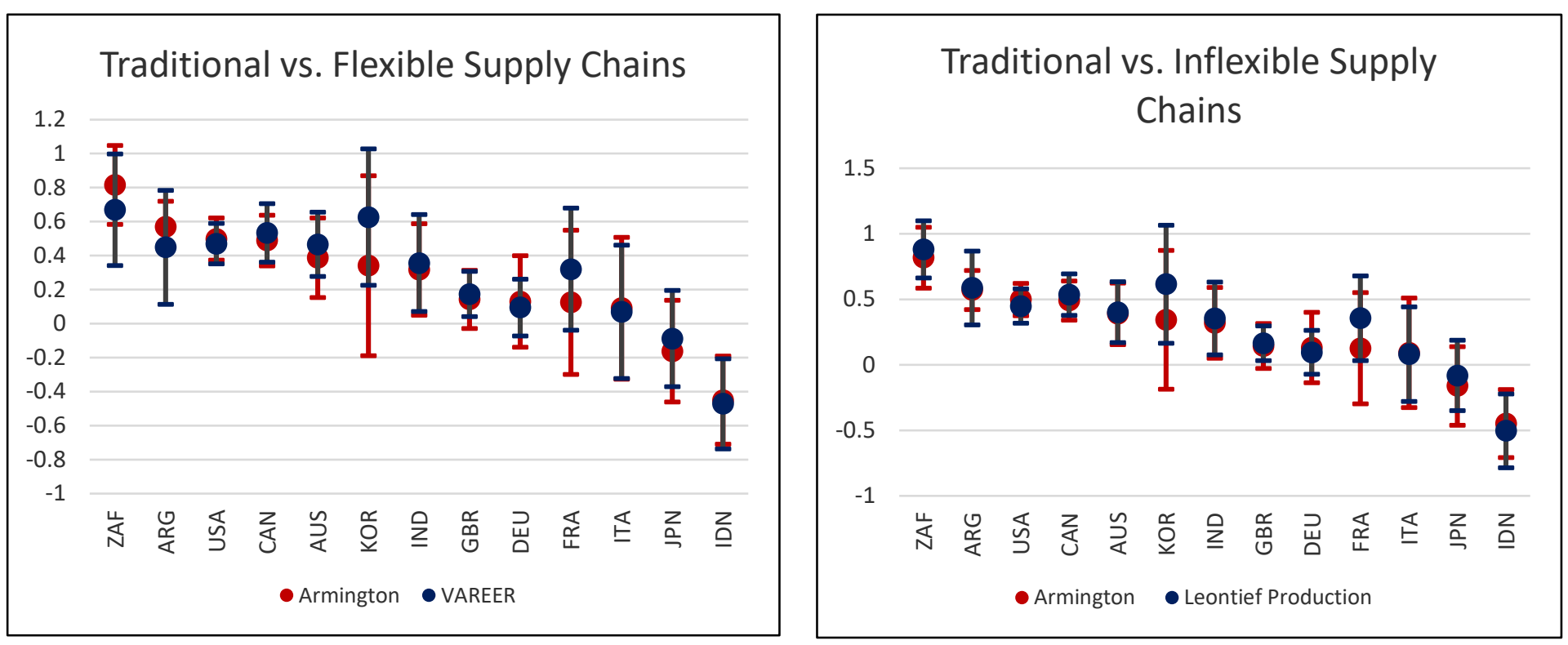

Figure A2.

Export Elasticities with different REER measures
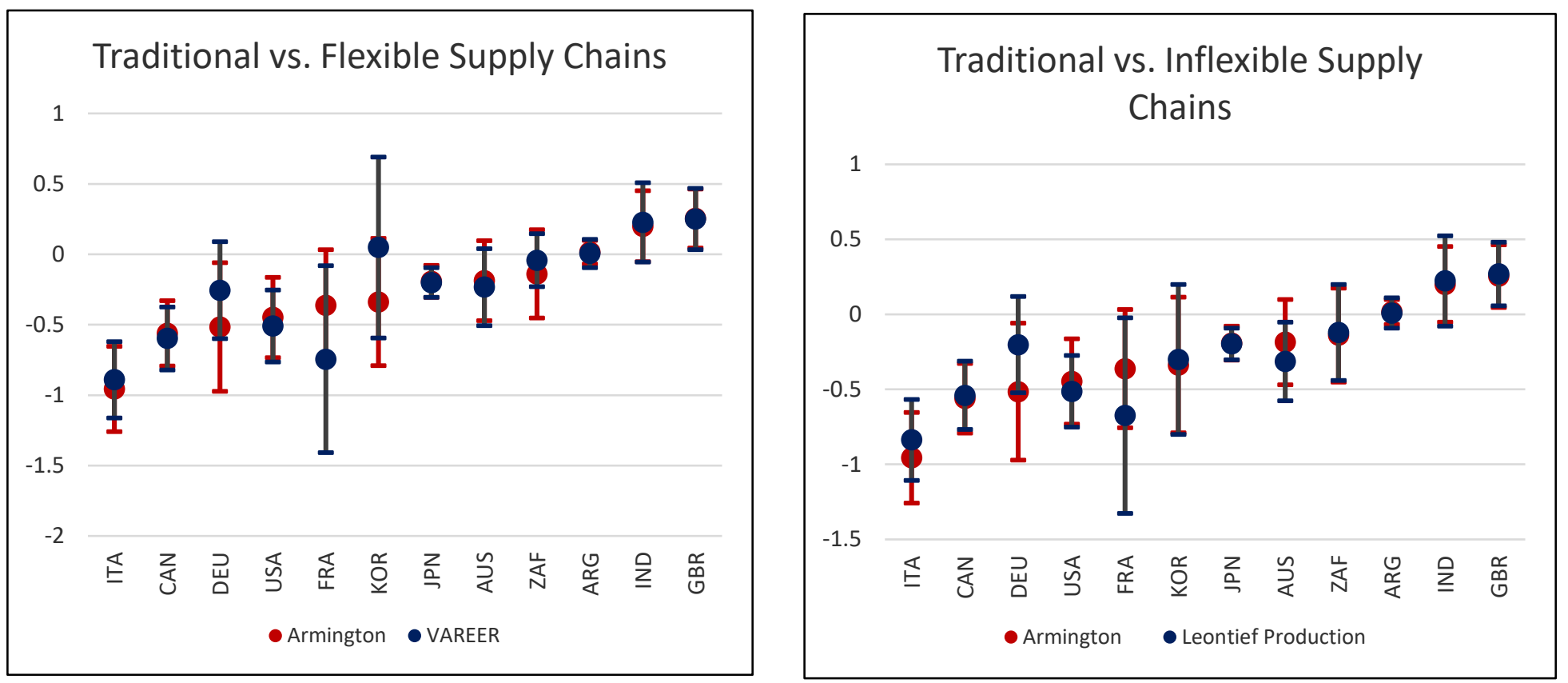


\section{REFERENCES}

Ahmed, Swarnali, Maximiliano Appendino and Michele Ruta (2017) "Global Value Chains and the Exchange Rate Elasticity of Exports” B.E. Journal of Macroeconomics [Advances] 17(1).

Armington, Paul S. (1969) "A Theory of Demand for Products Distinguished by Place of Production,” IMF Staff Ppspers, Vol 16:1 March 1969, pp. 159-178.

Atalay, E (2017), “How Important Are Sectoral Shocks?” American Economic Journal: Macroeconomics, Vol. 9 (4), October 2017, pp. 254-280.

Barrot, J.-N. and J. Sauvagnat (2016), "Input Specificity and the Propagation of Idiosyncratic Shocks in Production Networks," Quarterly Journal of Economics (2016), 15431592.

Bayoumi, Tamim, Jaewoo Lee, and Sharma Jayanthi (2005) "New Rates form New Weights,” IMF Working Paper WP/05/99.

Bayoumi, Tamim, Mika Saito, and Jarkko Turunen (2013) "Measuring Competitiveness: Trade in Goods or Tasks?” IMF Working Paper WP/13/100.

Bems, Rudolfs and Robert C. Johnson (2017) "Demand for Value Added and Value-Added Exchange Rates,” American Economic Journal: Macroeconomics 9(4).

Boehm, C., A. Flaaen and N. Pandalai-Nayar. Forthcoming. "Input Linkages and the Transmission of Shocks: Firm Level Evidence from the 2011 Tohoku Event," forthcoming at Review of Economics and Statistics.

Boz, E., G. Gopinath and M. Plagborg-Møller. 2018. "Global Trade and the Dollar,” mimeo.

Broda, C. and D.E. Weinstein. 2006. "Globalization and the Gains from Variety," Quarterly Journal of Economics, May 2006, pp. 541-585.

Burstein, A., C. Kurz and L. Tesar. 2008. "Trade, production sharing and the international transmission of business cycles," Journal of Monetary Economics, May 2008.

Cheng, Kevin C., Gee Hee Hong, Dulani Seneviratne, and Rachel van Elkan (2016) "Rethinking the Exchange Rate Impact on Trade in a World with Global Value Chains," International Economic Journal, 30:2, 204-216.

De Soyres, F. (2017), "Value Added and Productivity Linkages Across Countries," mimeo. 
Durand, M., J. Simon and C. Webb (1992), “OECD's Indicators of International Trade and Competitiveness," OECD Economics Department Working Papers, No. 120.

Gopinath, G. and R. Rigobon (2008), "Sticky Borders," Quarterly Journal of Economics, Vol. 123 (2), pp. 531-575.

IMF (2013). "Trade Interconnectedness: The World With Global Value Chains,” August 2013.

IMF (2015). “Exchange Rates and Trade Flows: Disconnected?” World Economic Outlook, October 2015.

Johnson, Robert C. and Guillermo Noguera, "A Portrait of Trade in Value Added Over Four Decades," The Review of Economics and Statistics, Vol. 99, Issue 5, pp. 896-911.

Klau, Marc and San Sau Fung (2006) "The new BIS effective exchange rate indices”, BIS Quarterly Review, March 2006, pp. 51-65.

Loretan, Mico (2005) "Indexes of the Foreign Exchange Value of the Dollar," Federal Reserve Bulletin Winter 2005, pp. 1-8

McGuirk, Anne K. (1987) "Measuring Price Competitiveness for Industrial Country Trade in Manufactures," IMF Working Paper WP/87/34.

Patel, Nikhil, Zhi Wang, and Shang-Jin Wei (2017) "Global Value Chains and Effective Exchange Rates at a Country-Sector Level,” BIS Working Papers No 637.

Schmitz, Martin, Maarten De Clercq, Michael Fidora, Bernadette Lauro and Cristina Pinheiro (2012) "Revisiting and Effective Exchange Rates of the Euro," ECB Occasional Paper 134.

Turner, Philip and Jozef Van 't dack (1993) "Measuring international price and cost competitiveness," BIS Economic Papers No 39.

Zanello, Alessandro and Dominique Desruelle (1997) "A Primer on the IMF's Information Notice System,” IMF Working Paper WP/97/71. 